IFN Working Paper No. 997, 2013

\title{
More Open - Better Governed? Evidence from High- and Low-income Countries
}

Andreas Bergh, Irina Mirkina and Therese Nilsson 


\title{
More Open-Better Governed? Evidence from High- and Low-income Countries
}

\author{
Andreas Bergh, Research Institute of Industrial Economics (IFN) and Lund University \\ Irina Mirkina, IMT Institute for Advanced Studies
}

Therese Nilsson, Research Institute of Industrial Economics (IFN) and Lund University

Summary - Using World Bank data on institutional quality and the KOF Globalization Index, we examine over 100 countries from 1992 to 2010 to analyze the relationship between economic and social globalization and six measures of institutional quality. Theoretically, the incentives of elites to respond to globalization by improving institutions should differ between low-income and high-income countries. Empirically, increasing economic flows and social globalization are followed by improving institutions in rich countries, while the effect is the opposite for low-income countries. Previous findings of positive effects of trade on institutional quality are likely driven by rich countries.

Key words: globalization, institutional quality, developing countries

JEL-codes: H83, F63, O11

Financial support from the Marianne and Marcus Wallenberg Foundation, the Crafoord Foundation and the Jan Wallander and Tom Hedelius Foundation is gratefully acknowledged. 


\section{INTRODUCTION}

In Moscow, Russia, the Swedish furniture retailer IKEA was asked to pay a bribe only weeks before the opening of its flagship store in 2000. Refusal to pay would lead to electricity being shut down. IKEA responded, not by paying the bribe, but by renting diesel generators large enough to power the entire shopping mall. It was later revealed that the Russian executive hired to manage the diesel generators took kickbacks from the rental company to inflate the price. IKEA’s expansion in Russia was halted, and two years later senior executives were dismissed for allowing bribes.

The story about IKEA in Russia, told by among many others The New York Times ${ }^{1}$, illustrates important aspects of globalization. Trade and foreign direct investments can potentially improve economic development, benefitting both consumers and capital owners. At the same time, dysfunctional institutions, such as corruption, may thwart these potential benefits. The establishment of and actions taken by firms operating in foreign countries may also affect norms and behavior. On the one hand, IKEA's refusal to pay bribes may facilitate the fight against corruption in Russia. On the other hand, the profits generated by IKEA increase the potential gains from engaging in corrupt behavior. It is therefore not clear how the degree of corruption in Russia would change as a result of IKEA's ventures. More generally, little is known about the effects of globalization on institutional quality. This paper aims to shed light on this particular question: Is increasing globalization on average followed by improving or deteriorating institutional quality?

\footnotetext{
${ }^{1}$ Kramer (2009), “Ikea Tries to Build Public Case Against Russian Corruption”. The New York Times, September 11, 2009.
} 
Changing institutions will generally involve trade-offs between short- and long run benefits. Consequently, the time horizon and expectations of those who influence institutions - the institutional entrepreneurs - will be crucial in determining the effects of increased globalization. As the time horizon often is determined by the level of economic development where the institutional entrepreneur is active, it is important to shed light on whether the globalization effect on institutional quality varies across levels of development.

Using the World Bank’s Worldwide Governance Indicators (WGI) to capture several aspects of institutional quality and the KOF Globalization Index to measure economic and social globalization, we construct a panel data set covering over 101 countries from 1992 to 2010, and regress several measures of institutional quality (averaged over four years) on lagged indicators of globalization. As suggested by the findings in Haggard and Tiede (2011), we examine different types of institutional quality separately, and we avoid what Blonigen and Wang (2005) call 'inappropriate pooling of wealthy and poor countries' by using both sample splits and interaction effects. In line with our theoretical predictions, results reveal that globalization is typically followed by improved institutional quality in rich countries, but in poor countries this relationship is the opposite. Despite institutions changing slowly over time, many correlations are statistically significant and the difference between rich and poor countries is highly robust.

The paper proceeds as follows. The next section discusses theoretically how globalization and economic openness is expected to affect institutions and reviews recent research. Section 3 discusses the measurement of institutions and presents the data, while Section 4 contains the empirical analysis, including several robustness checks and tests the relationship between globalization and institutional quality across levels of development. Section 5 concludes the paper by summarizing our results and discusses how to interpret the findings. 


\section{THEORETICAL FRAMEWORK AND EMPIRICAL EVIDENCE}

\section{(a) Theoretical expectations}

North (1990) defined institutions as "rules of the game" that shape human interaction (p. 3) and argued that "third world countries are poor because the institutional constraints define a set of payoffs to political/economic activity that does not encourage productive activity” (p. 110). A large following literature has empirically confirmed the quality of institutions as an important determinant of economic growth: Knack and Keefer (1995), Rodrik et al. (2004), Abdiweli (2003) and Doucouliagos and Ulubasoglu (2006) to mention just a few. ${ }^{2}$ There is no complete agreement on what institutions matter the most, though the survey by Durlauf et al. (2005) points to low corruption, political stability, property rights and rule of law all being important for development. The importance of low corruption for growth is also confirmed by Haggard and Tiede (2011).

As the evidence of the importance of institutional quality accumulates, it is natural to examine if and how institutions change. Institutions shape human interaction, but at the same time institutions are enforced and upheld by human interaction. According to North (1981), institutional change is incremental and occurs when influential agents perceive they could do better by altering the existing institutional framework. Li et al. (2005) define an institutional entrepreneur as an innovative person who changes prevailing institutions to improve business opportunities, and provide several examples of how institutions such as labour regulation, entry barriers and property rights have been changed as a result of such individual initiatives.

\footnotetext{
${ }^{2}$ However, Richter and Timmons (2012) argue that the size of the effect institutions have on economic growth is relatively small.
} 
In general, there are reasons to expect at least some aspects of globalization to be beneficial for institutional quality. A fundamental reason to expect trade and economic openness to improve institutional quality is Montesquieu's idea that market interactions act as a civilizing force. ${ }^{3}$ Differences in institutional quality across countries can also be seen as a source of comparative advantage. As discussed in Bergh and Höijer (2008), globalization can increase the competition between countries with different institutions, fostering institutional reforms in countries with low institutional quality.

Finally, as discussed by Al-Marhubi (2005), globalization may also affect institutions through closer integration and openness, coming with an increasing global flow of information that provides alternative sources for knowledge and ideas. Such information spill-overs may make citizens more demanding and help nurture civil institutions. While the OECD focus specifically on citizens' role in policymaking (OECD, 2009), information spill-overs are also likely to affect institutional quality in a low-income setting. A recent illustrative example is the initiatives to tackle corruption in developing countries by encouraging anonymous reports of bribe-payingusing public websites. ${ }^{4}$ Such activities may improve governance systems and procedures and reduce the scope for corruption.

Other mechanisms are more neutral. For example, globalization is likely to change the distribution of power within countries through, for example, the transmission of technology (Romer, 1990). In this case, globalization leads to changes in the distribution of the ability to influence a country's institutions. Along these lines, Acemoglu and Robinson (2006) show

\footnotetext{
3 “[w] herever manners are gentle there is commerce, and wherever there is commerce, manners are gentle" (Montesquieu 1749, cited in Hirschman 1982).

${ }^{4}$ See e.g. www.ipaidabribe.com - a website covering information reported by anonymous individuals on when having to pay a bribe in more than 450 Indian cities.
} 
that the trade induced transfers of skill-biased technology increase the income share of the middle class, in turn improving their political power and ultimately generating better protected property rights. Although institutions tend to be persistent, changes may consequently occur when an exogenous shock, such as the opening of an economy to the world market, modifies the societal power balance. ${ }^{5}$

Changing institutions will in many cases involve trade-offs between short run and long run benefits. For example, both violations of rule of law and of property rights are likely to bring short run gains to those involved, while harming the long run economic development. The same goes for corruption and several policy rules as well, such as inflationary monetary policies, which may bring substantial benefits to small elite groups in the short run while being devastating for long run economic development.

For this reason, the time horizon and expectations of those who influence institutions will be crucial in determining the effects of increased globalization. Referring again to the case of IKEA in Russia, it may be the case that those who engage in corrupt activity realize that corruption is likely to diminish the long run benefits from having IKEA expanding in Russia, but when future benefits are heavily discounted, the short run benefits of increased corruption are higher. In the latter case, the presence of IKEA creates an incentive for elites to alter institutions so as to easier reap short run benefits from corruption, property rights violations and similar activities. If, however, more weight is put on long run economic development, the effect of IKEA would be to increase the return to institutional improvements.

\footnotetext{
${ }^{5}$ Economic theory and empirical evidence suggest that globalization generates economic growth (see e.g. Dreher, 2006). From the above discussion various institutional changes may consequently be seen as potential mechanisms in that relationship.
} 
In poor countries, uncertainty and instability is typically higher, and life expectancy is shorter. Consequently, the incentives to improve institutions to foster long run economic development are lower, and the incentives to worsen institutions (through, for example, accepting corruption) are higher (see Acemoglu and Verdier,2000; Fjeldstad and Tungodden, 2003; and Altindag and $\mathrm{Xu}$, 2009) for further discussions). Thus, the correlation between globalization and subsequent improvements in institutional quality when examined using panel data with country fixed effects is expected to be smaller (and possibly negative) in poor countries than in rich countries.

\section{(b) Previous literature}

In the wake of increasing globalization, several studies have examined whether factors such as trade and economic openness affect institutions, especially rule of law and the level of corruption. But no study has noted that the effect of globalization on institutions is likely to depend on the level of development as suggested by the time horizon argument given above. As a result, existing research potentially suffers from inappropriate pooling of low-income and high-income countries (Blonigen and Wang, 2005). Table 1 summarizes six recent papers that examine an effect of economic openness on institutional characteristics. 
Table 1. Studies of the relationship between openness and institutions

\begin{tabular}{|c|c|c|c|c|}
\hline Study & Measure of institutions & Measure of openness & Data & Results \\
\hline $\begin{array}{l}\text { Bhattacharyy } \\
\text { a (2012) }\end{array}$ & $\begin{array}{l}\text { Expropriation risk and } \\
\text { repudiation of contracts } \\
\text { (International Country Risk } \\
\text { Guide) }\end{array}$ & $\begin{array}{l}\text { Number of years with openness } \\
\text { according to the Sachs and } \\
\text { Warner openness index updated } \\
\text { by Wacziarg and Welch (2003) }\end{array}$ & $\begin{array}{l}\text { Panel data, 65-103 } \\
\text { countries, } 1980-2000\end{array}$ & $\begin{array}{l}\text { A one sample standard deviation (0.5) increase in the } \\
\text { fraction of years a country has remained open since } \\
\text { 1950leads to a } 2.2 \text { points increase in the property rights } \\
\text { institutions index. } \\
\text { Trade instrumented using export partners' growth rate. }\end{array}$ \\
\hline $\begin{array}{l}\text { Levchenko } \\
\text { (2011) }\end{array}$ & $\begin{array}{l}\text { Rule of law index from } \\
\text { (Kaufmann et al. 2005) average } \\
\text { across 1996-2000 }\end{array}$ & $\begin{array}{l}\text { Institutional intensity of exports } \\
\text { of each country predicted by } \\
\text { exogenous geographic } \\
\text { characteristics }\end{array}$ & $\begin{array}{l}\text { Cross section for } 141 \\
\text { countries, averages } \\
1970-1999\end{array}$ & $\begin{array}{l}\text { Countries whose exogenous geographical characteristics } \\
\text { predispose them to exporting in institutionally intensive } \\
\text { sectors enjoy significantly higher institutional quality. }\end{array}$ \\
\hline $\begin{array}{l}\text { Nicolini and } \\
\text { Paccagnini } \\
\text { (2011) }\end{array}$ & $\begin{array}{l}\text { Political rights and Civil } \\
\text { liberties (Freedom house) }\end{array}$ & Trade flows/GDP & $\begin{array}{l}\text { Panel data, } 197 \\
\text { countries, } 976-2004 .\end{array}$ & $\begin{array}{l}\text { No causality between trade and institutions (in any } \\
\text { direction) }\end{array}$ \\
\hline $\begin{array}{l}\text { Al-Marhubi } \\
\text { (2005) }\end{array}$ & $\begin{array}{l}\text { Average of the six Kaufmann } \\
\text { (1999) dimensions (same as } \\
\text { Knack \& Keefer, 1995) }\end{array}$ & $\begin{array}{l}\text { Trade flows. Sachs \& Warner } \\
\text { index, the D-index (Dollar, 1992) } \\
\text { and EFI4 (Gwartney \& Lawson, } \\
\text { 2002) as robustness tests }\end{array}$ & $\begin{array}{l}81-125 \text { countries. } \\
\text { Cross section using } \\
\text { trade flows in } 1985 \\
\text { and institutions 2000- } \\
2001\end{array}$ & $\begin{array}{l}\text { Openness improves governance (robust to all openness } \\
\text { measures except the D-index) }\end{array}$ \\
\hline Wei (2000) & $\begin{array}{l}\text { Corruption (Business } \\
\text { International, Transparency } \\
\text { International) }\end{array}$ & Trade flows/GDP & $\begin{array}{l}\text { Cross section of } 169 \\
\text { countries } 1978-80 \text { and } \\
184 \text { countries } \\
1994-96\end{array}$ & More open economies exhibit less corruption. \\
\hline $\begin{array}{l}\text { Bonaglia et } \\
\text { al. (2001) }\end{array}$ & $\begin{array}{l}\text { Corruption ( } \\
\text { Transparency International, } \\
\text { International Country Risk } \\
\text { Guide) }\end{array}$ & Imports/GDP & $\begin{array}{l}53-119 \text { countries, } \\
\text { Pooled OLS for } \\
\text { various periods } 1980- \\
1998\end{array}$ & $\begin{array}{l}\text { Import openness decreases corruption. Results robust in } \\
\text { IV-regressions where population, English speaking } \\
\text { dummy, area, and remoteness are used as instruments for } \\
\text { openness. }\end{array}$ \\
\hline
\end{tabular}


Research so far lends some support to the view that economic openness on average promotes institutional improvement. Wei (2001) and Bonaglia et al. (2001) both suggest that more open economies exhibit less corruption and the findings by Al-Marhubi (2005) indicate that more globalized countries have better governance.

Several caveats however apply in the existing literature. Only two studies so far use panel data. Cross-sectional studies rely on variation between countries to estimate an effect of openness on institutional quality, restricting our knowledge with respect to the causality of the relationships. While some plausible time-invariant instruments for economic openness have been used, effects in cross-sectional studies are not identified using within-country variation. For example, Levchenko (2011) shows that countries whose geographical characteristics predispose them to export in so called institutionally intensive sectors have higher institutional quality. Importantly, this finding does not imply that an increase in trade flows is followed by institutional improvement.

The two existing panel data studies arrive at different results. Bhattacharyya (2012) finds that the longer a country has been open according to the Sachs and Warner index updated by Wacziarg and Welch (2003), the better protected are private property rights as measured by expropriation risk and repudiation of contracts in the International Country Risk Guide. Conversely, using yearly bilateral trade flow data and the Freedom House index for political rights and civil liberties, Nicolini and Paccagnini (2011) do not find any causality from trade to institutions, nor vice versa. Given that institutions change slowly over time, the result may however be driven by their use of yearly data.

Finally, the literature on globalization and institutional quality has so far employed strict economic measures of globalization, such as trade flows or the Sachs Warner index that classifies a country as either open or not. The process of globalization, however, is a broad 
and multidimensional phenomenon with economic, social and political components (Arribas et al., 2009; Dreher et al., 2008) that may affect institutions differently, suggesting that a strict focus on economic measures might limit our understanding of the relationship between globalization and institutional change.

\section{DATA AND METHODS}

(a) Data - Institutional quality and globalization

Choosing a measure of institutional quality involves several tradeoffs. For some particular institutions, such as democracy, data are available for all major states since 1800 in the Polity IV Project. Other institutional measures are more comprehensive, but cover much fewer countries and years. ${ }^{6}$ Our choice is the Worldwide Governance Indicators (WGI) by the World Bank (Kaufmann et al., 2010). This dataset captures several aspects of institutional quality, begins in 1996 and covers 193 countries by 2010, and has not been used before in this line of research. Inference using year to year changes is not advised, but averaging over short time periods yields a reasonably comprehensive measure of various aspects of institutional quality for both high-income and low-income countries.

For interpretation, it is important to know that the WGI compile and summarize information from several sources, including both expert assessments such as the CPIA assessments (used by Chauvet and Collier 2008) and public surveys (such as the Afrobarometer surveys). Each source is assigned to one of six aggregate indicators, which are averaged and made comparable across countries using an unobserved components model. The crucial assumption in this procedure is that the observed data from each source are a linear function of the

\footnotetext{
${ }^{6}$ A good collection of available institutional data is accessible through the Quality of Governance (QoG) dataset by the University of Gothenburg (Teorell et al., 2011).
} 
underlying, unobserved level of governance. ${ }^{7}$ The six aggregate indicators are government effectiveness (GE), control of corruption (CC), regulatory quality (RQ), political stability (PS), rule of law (RL), and voice and accountability (VA). Previous studies such as Knack and Keefer (1995) and Al-Marhubi (2005) use the average of these indicators. The findings in Haggard and Tiede (2011), however, suggest that developing countries vary in the way different types of institutional quality are combined. Specifically, they note that a large cluster of developing countries combines high corruption levels with relatively well functioning property rights, whereas a second smaller cluster is worse in both dimensions and also very violent. We therefore use these six indicators separately instead of averaging them. Details of the six measures are presented in the appendix.

To measure globalization, we use the log of the KOF index (Dreher et al., 2008) covering most countries in the world from 1970 onwards, that allows us to examine separately the effects of economic globalization (i.e. economic policies and economic flows) and social globalization (i.e. personal contacts, information flows, and cultural proximity) across countries. Details of the KOF index and its sub-components are presented in the appendix. As an illustration, figure 1 plots the change in economic globalization as measured by the KOF index against the change in government effectiveness from the WGI over the period 1996-2009. As expected, the scatter plot illustrates that most countries experienced increasing economic globalization over the period. Interestingly, focusing on the upper part of the figure shows that a number of countries substantially improved their institutional quality during the same time period.

\footnotetext{
${ }^{7}$ More details are available on http://info.worldbank.org/governance/wgi/resources.htm
} 
Figure 1 suggests a weak positive correlation between globalization and institutional quality. Variation is however large among observations and differentiating between rich and poor countries allows us to see a somewhat stronger correlation seeming to exist in high-income contexts. Furthermore, figure 1 reveals that there are no obvious outliers in the sample.

Figure 1. Change in economic globalization and change in government effectiveness for highincome and low-income countries, 1996-2009

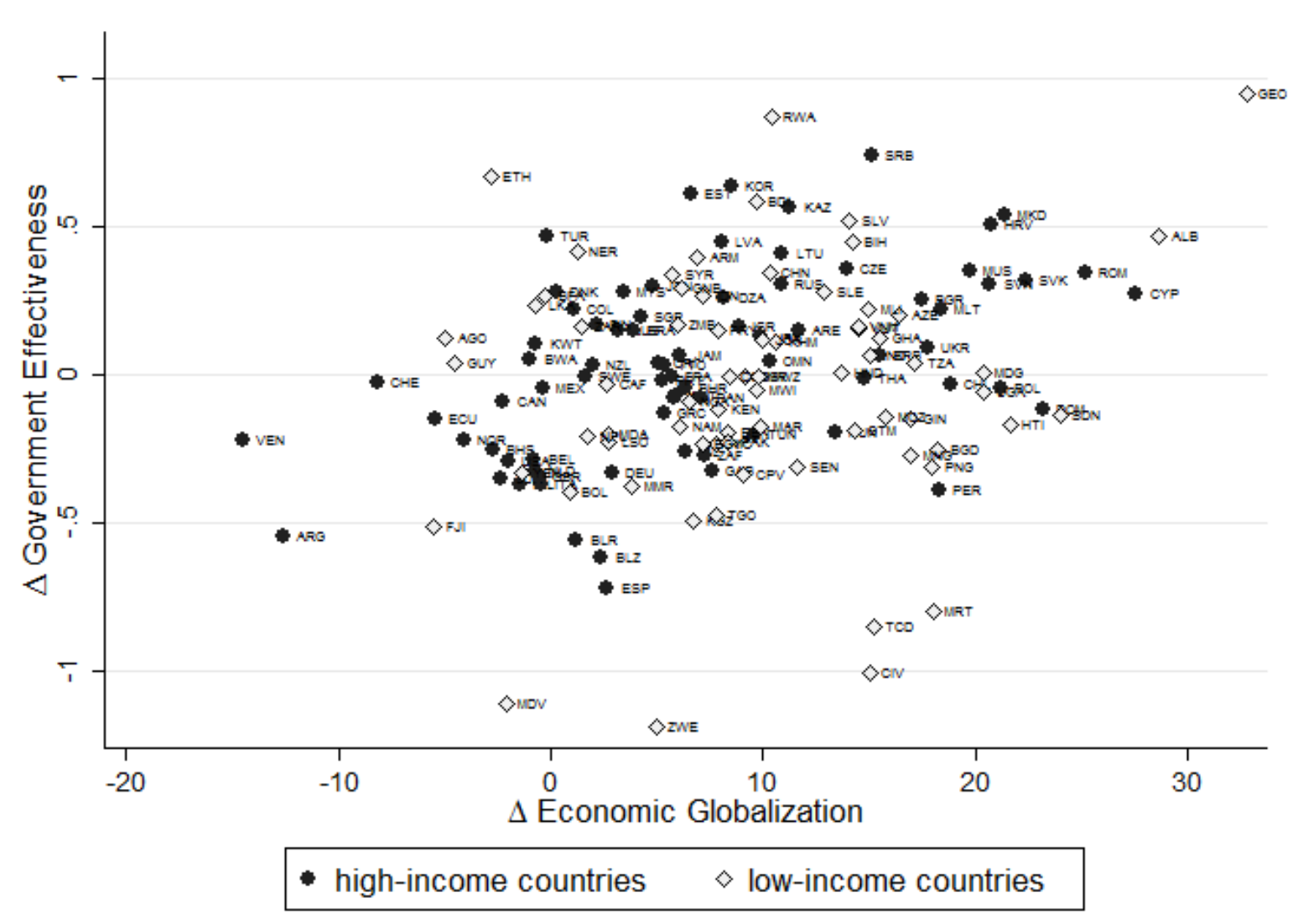




\section{(b) Data-Control variables}

The baseline specification includes several control variables, all suggested by previous empirical research on the determinants of institutional quality. GDP per capita (PPP adjusted, in constant USD), total population (both in logs), and share of total rent from natural resources in GDP are taken from the World Development Indicators (WDI) database (World Bank, 2010). Population is used as a proxy for country size. While richer countries typically have better institutions, the findings of Treisman (2000) and Fisman and Gatti (2002) suggest that country size has the opposite effect, presumably due to the difficulties in sharing of power and responsibilities between central and local authorities. Rent from natural resources is included to measure natural resources abundance, found associated with higher levels of corruption by both Ades and Di Tella (1999) and Treisman (2000), and also with lower quality of government in general by Anthonsen et al. (2012).

Additional controls are used as robustness checks, including the log of total net development assistance and aid from the WDI, the percentage of adult population (age > 15) with completed secondary education (Barro and Lee, 2010), and the Polity IV index ranking a country's political institutions by giving each country a score from -10 to 10 , ranging from pure autocracy to consolidated democracy (Marshall and Jaggers, 2012).

Table 2 shows descriptive statistics on the variables of interest. 
Table 2. Descriptive statistics

\begin{tabular}{|c|c|c|c|c|c|c|c|}
\hline Variable & Mean & Std.dev. & $\mathrm{n}$ & $\mathrm{N}$ & Min & Max & Source \\
\hline Government effectiveness & -0.06 & 1 & 191 & 752 & -2.32 & 2.30 & $\begin{array}{l}\text { Worldwide Governance } \\
\text { Indicators (2011) }\end{array}$ \\
\hline Control of corruption & -0.06 & 1 & 191 & 752 & -1.92 & 2.51 & $\begin{array}{l}\text { Worldwide Governance } \\
\text { Indicators (2011) }\end{array}$ \\
\hline Political stability & -0.05 & 1 & 193 & 758 & -3.23 & 1.64 & $\begin{array}{l}\text { Worldwide Governance } \\
\text { Indicators (2011) }\end{array}$ \\
\hline Regulatory quality & -0.07 & 1 & 191 & 752 & -2.53 & 2.16 & $\begin{array}{l}\text { Worldwide Governance } \\
\text { Indicators (2011) }\end{array}$ \\
\hline Rule of law & -0.07 & 1 & 193 & 763 & -2.53 & 1.96 & $\begin{array}{l}\text { Worldwide Governance } \\
\text { Indicators (2011) }\end{array}$ \\
\hline Voice and accountability & -0.04 & 1 & 193 & 769 & -2.22 & 1.67 & $\begin{array}{l}\text { Worldwide Governance } \\
\text { Indicators (2011) }\end{array}$ \\
\hline Log of Economic globalization & 3.99 & 0.35 & 148 & 739 & 2.31 & 4.58 & $\begin{array}{l}\text { Dreher et al. (2008), } \\
\text { updated in } 2012\end{array}$ \\
\hline $\begin{array}{l}\text { Log of Economic globalization: } \\
\text { Flows }\end{array}$ & 4.00 & 0.41 & 173 & 864 & 2.21 & 4.61 & $\begin{array}{l}\text { Dreher et al. (2008), } \\
\text { updated in } 2012\end{array}$ \\
\hline $\begin{array}{l}\text { Log of Economic globalization: } \\
\text { Restrictions }\end{array}$ & 3.95 & 0.46 & 137 & 684 & 1.60 & 4.57 & $\begin{array}{l}\text { Dreher et al. (2008), } \\
\text { updated in } 2012\end{array}$ \\
\hline Log of Social globalization & 3.67 & 0.55 & 183 & 912 & 1.82 & 4.53 & $\begin{array}{l}\text { Dreher et al. (2008), } \\
\text { updated in } 2012\end{array}$ \\
\hline $\begin{array}{l}\text { Log of Social globalization: } \\
\text { Personal contacts }\end{array}$ & 3.80 & 0.54 & 179 & 892 & 1.85 & 4.59 & $\begin{array}{l}\text { Dreher et al. (2008), } \\
\text { updated in } 2012\end{array}$ \\
\hline $\begin{array}{l}\text { Log of Social globalization: } \\
\text { Information flows }\end{array}$ & 3.96 & 0.47 & 175 & 872 & 1.48 & 4.60 & $\begin{array}{l}\text { Dreher et al. (2008), } \\
\text { updated in } 2012\end{array}$ \\
\hline $\begin{array}{l}\text { Log of Social globalization: } \\
\text { Cultural proximity }\end{array}$ & 2.78 & 1.28 & 190 & 947 & 0.69 & 4.59 & $\begin{array}{l}\text { Dreher et al. (2008), } \\
\text { updated in } 2012\end{array}$ \\
\hline Log of GDP per capita, PPP & 8.49 & 1.29 & 168 & 868 & 5.25 & 11.18 & $\begin{array}{l}\text { World Development } \\
\text { Indicators (2012) }\end{array}$ \\
\hline Log of Population size & 15.46 & 2.10 & 190 & 945 & 9.72 & 21.00 & $\begin{array}{l}\text { World Development } \\
\text { Indicators (2012) }\end{array}$ \\
\hline $\begin{array}{l}\text { Total natural resources rent (\% } \\
\text { of GDP) }\end{array}$ & 9.06 & 17.16 & 185 & 922 & 0 & 164.95 & $\begin{array}{l}\text { World Development } \\
\text { Indicators (2012) }\end{array}$ \\
\hline $\begin{array}{l}\text { Percentage of population (age } \\
15+\text { ) with completed secondary } \\
\text { education }\end{array}$ & 20.56 & 13.53 & 142 & 710 & 0.60 & 67.79 & Barro and Lee (2010) \\
\hline $\begin{array}{l}\text { Log of Net development } \\
\text { assistance and aid }\end{array}$ & 19.03 & 1.55 & 139 & 774 & 12.61 & 23.19 & $\begin{array}{l}\text { World Development } \\
\text { Indicators (2012) }\end{array}$ \\
\hline $\begin{array}{l}\text { Revised combined Polity IV } \\
\text { score }\end{array}$ & 3.02 & 6.57 & 159 & 791 & -10 & 10 & $\begin{array}{l}\text { Marshall and Jaggers } \\
\text { (2012) }\end{array}$ \\
\hline
\end{tabular}




\section{(c) Method}

To examine the relationships between globalization and institutional quality, we specify the following equation

$\mathrm{IQ}_{\text {it }}=\underset{\mathrm{i}}{\alpha}+\underset{\mathrm{i} \text { it }-1}{\beta \mathrm{G}}+\underset{\mathrm{i}}{\gamma \mathrm{X}-1}+\mathrm{u}_{\text {it }}$

where IQ stands for institutional quality, $G$ is globalization, $X$ refers to a set of controls, and $u_{i t}$ is the error term. To account for unobservable heterogeneity potentially correlated with the explanatory variables, we include country fixed effects but we also run a random effects model as a robustness check. ${ }^{8}$

The model is estimated using four year averages over five periods: 1992-1995, 1996-1999, 2000-2003, 2004-2007, and 2008-2010. Averages are used to minimize the effects of noise and single year fluctuations in the data. To mitigate potential endogeneity, independent variables are lagged, so that average globalization from 1992-1995 is used to explain institutional quality over 1996-1999. The only variable that is used with its actual values is a share of population with secondary education, as this data only covers the years 1990, 1995, 2000, 2005, and 2010. To enhance comparability across different specifications, we don’t allow the sample to vary across the models of the same specification, thus, the effective sample is limited by data availability. To allow for different effects in developed and developing countries, we divide the full sample into sub-samples of high-income and lowincome countries (with the threshold at GDP per capita of 4000 USD).

\footnotetext{
${ }^{8}$ The main specification does not include time fixed effects as shocks simultaneously affecting institutional quality in several countries are unlikely. When including time fixed effects, time dummies are not jointly significant at traditional levels.
} 


\section{RESULTS}

(a) Main results

Tables 3 and 4 present fixed effects estimation results for the relationship between economic and social globalization and the six dimensions of institutional quality, using the full sample. Economic globalization seems to be followed by improving institutions, with four of the six dimensions reaching statistical significance at least at the ten percent level. In contrast, the estimates for social globalization are small and never significant. The control variables generally have the expected sign, with population size and rents from natural resources being negatively related to institutional quality. 
Table 3. Economic globalization: baseline models; full sample. Explanatory variables lagged.

\begin{tabular}{|c|c|c|c|c|c|c|}
\hline & $\begin{array}{l}\text { Government } \\
\text { Effectiveness } \\
\text { (GE) }\end{array}$ & $\begin{array}{l}\text { Control of } \\
\text { Corruption } \\
\text { (CC) }\end{array}$ & $\begin{array}{l}\text { Regulatory } \\
\text { Quality } \\
\text { (RQ) }\end{array}$ & $\begin{array}{l}\text { Voice and } \\
\text { Accountability } \\
\text { (VA) }\end{array}$ & $\begin{array}{l}\text { Rule of } \\
\text { Law } \\
\text { (RL) }\end{array}$ & $\begin{array}{l}\text { Political } \\
\text { Stability } \\
\text { (PS) }\end{array}$ \\
\hline \multirow[t]{2}{*}{ Economic Globalization } & 0.114 & 0.113 & 0.262 & 0.304 & 0.208 & 0.248 \\
\hline & (1.49) & $(1.19)$ & $(2.84)^{* * *}$ & $(3.22)^{* * *}$ & $(2.54)^{* *}$ & $(1.73)^{*}$ \\
\hline \multirow[t]{2}{*}{ Population } & -0.468 & -0.253 & -0.622 & -0.082 & -0.354 & -0.232 \\
\hline & $(4.08)^{* * *}$ & $(1.78)^{*}$ & $(4.50)^{* * *}$ & $(0.58)$ & $(2.88)^{* * *}$ & $(1.08)$ \\
\hline \multirow[t]{2}{*}{ GDP per Capita, PPP } & 0.266 & -0.023 & 0.057 & -0.168 & 0.073 & 0.025 \\
\hline & $(3.91)^{* * *}$ & $(0.27)$ & $(0.69)$ & $(2.01)^{* *}$ & (1) & $(0.2)$ \\
\hline \multirow[t]{2}{*}{ Total natural resources rents } & -0.002 & -0.005 & -0.004 & -0.006 & -0.005 & -0.002 \\
\hline & $(0.7)$ & $(1.79)^{*}$ & $(1.62)$ & $(2.04)^{* *}$ & $(2.17)^{* *}$ & $(0.43)$ \\
\hline \multirow[t]{2}{*}{ Constant } & 4.715 & 3.543 & 8.473 & 1.323 & 4.012 & 2.251 \\
\hline & $(2.66)^{* * *}$ & $(1.62)$ & $(3.98)^{* * *}$ & $(0.61)$ & $(2.12)^{* *}$ & $(0.68)$ \\
\hline Observations & 392 & 392 & 392 & 392 & 392 & 392 \\
\hline Number of Countries & 101 & 101 & 101 & 101 & 101 & 101 \\
\hline R-squared & 0.11 & 0.03 & 0.09 & 0.05 & 0.06 & 0.02 \\
\hline
\end{tabular}

Absolute value of $t$ statistics in parentheses

* significant at $10 \%$; ** significant at $5 \%$; *** significant at $1 \%$ 
Table 4. Social globalization: baseline models; full sample

\begin{tabular}{lllllll}
\hline & GE & CC & RQ & VA & RL & PS \\
\hline Social Globalization & 0.04 & -0.088 & 0.066 & -0.005 & -0.097 & -0.179 \\
& $(0.54)$ & $(0.94)$ & $(0.73)$ & $(0.05)$ & $(1.21)$ & $(1.29)$ \\
Population & -0.295 & 0.06 & -0.314 & 0.207 & -0.017 & 0.219 \\
& $(2.56)^{* *}$ & $(0.41)$ & $(2.24)^{* *}$ & $(1.43)$ & $(0.14)$ & $(1.02)$ \\
GDP per Capita, PPP & 0.284 & 0.053 & 0.135 & -0.046 & 0.209 & 0.215 \\
& $(4.29)^{* * *}$ & $(0.64)$ & $(1.68)^{*}$ & $(0.55)$ & $(2.93)^{* * *}$ & $(1.75)^{*}$ \\
Total natural resources rents & -0.003 & -0.008 & -0.004 & -0.007 & -0.007 & -0.002 \\
& $(1.72)^{*}$ & $(3.12)^{* * *}$ & $(1.81)^{*}$ & $(2.65)^{* * *}$ & $(3.18)^{* * *}$ & $(0.66)$ \\
Constant & 2.041 & -1.376 & 3.573 & -3.188 & -1.393 & -4.986 \\
& $(1.16)$ & $(0.62)$ & $(1.66)^{*}$ & $(1.44)$ & $(0.73)$ & $(1.52)$ \\
Observations & 417 & 417 & 417 & 417 & 417 & 417 \\
Number of Countries & 109 & 109 & 109 & 109 & 109 & 109
\end{tabular}

Absolute value of $\mathrm{t}$ statistics in parentheses

* significant at $10 \%$; ** significant at $5 \%$; *** significant at $1 \%$

Running separate regressions for low-income and high-income countries drastically changes the results, in line with our theoretical expectations. In particular the positive relationship between economic globalization and institutional quality in the baseline analysis seems to be fully driven by the relationship in richer countries. Similarly, social globalization improves institutional quality in high-income countries during the time period studied. On the other hand, economic globalization is not correlated with institutional quality in the less developed context, and social globalization is negative and significant for four out of six institutional measures.

To gain deeper knowledge on what factors in the globalization process affect institutional quality, we further disaggregate the economic and social globalization measures. Tables 5 and 
table 6 present the effects of five types of globalization on the six dimensions of institutional quality for low-income and high-income countries separately.

The results reveal some patterns that are not visible in the pooled sample:

- Economic flows correlate with worsened institutions in low-income countries, with significant effects for government effectiveness and control of corruption. For rich countries, the sign is the opposite for all dimensions, and significantly so for government effectiveness, control of corruption and political stability.

- The personal contacts as a part of social globalization correlate negatively with institutional quality in low-income countries, but not in high-income countries.

- Both cultural proximity and information flows are followed by institutional improvements, often with significant effects, in high-income countries but not in lowincome countries.

- More liberal trade policies (as measured by the economic restrictions dimension of the KOF index) correlate with better institutions in low-income countries, but not so in high-income countries. 
Table 5. Different types of globalization; sub-sample of low-income countries (controls included but not shown)

\begin{tabular}{|c|c|c|c|c|c|c|}
\hline & GE & CC & RQ & VA & $\mathrm{RL}$ & PS \\
\hline \multirow[t]{2}{*}{ Economic Flows } & -0.154 & -0.24 & -0.114 & -0.033 & -0.073 & -0.075 \\
\hline & $(2.10)^{* *}$ & $(2.75)^{* * *}$ & (1.49) & $(0.35)$ & $(0.92)$ & $(0.51)$ \\
\hline Number of Countries & 60 & 60 & 60 & 60 & 60 & 60 \\
\hline R-squared & 0.12 & 0.1 & 0.05 & 0.05 & 0.05 & 0.04 \\
\hline \multirow[t]{2}{*}{ Economic Restrictions } & 0.275 & 0.227 & 0.28 & 0.334 & 0.353 & 0.581 \\
\hline & $(3.24)^{* * *}$ & $(2.25)^{* *}$ & $(3.13)^{* * *}$ & $(3.26)^{* * *}$ & $(4.15)^{* * *}$ & $(3.51)^{* * *}$ \\
\hline Number of Countries & 52 & 52 & 52 & 52 & 52 & 52 \\
\hline R-squared & 0.12 & 0.04 & 0.07 & 0.1 & 0.12 & 0.08 \\
\hline \multirow[t]{2}{*}{ Personal Contacts } & -0.191 & -0.47 & -0.124 & -0.488 & -0.278 & -0.533 \\
\hline & $(1.35)$ & $(2.81)^{* * *}$ & $(0.81)$ & $(2.82)^{* * *}$ & $(1.87)^{*}$ & $(1.95)^{*}$ \\
\hline Number of Countries & 59 & 59 & 59 & 59 & 59 & 59 \\
\hline R-squared & 0.08 & 0.08 & 0.01 & 0.1 & 0.06 & 0.05 \\
\hline \multirow[t]{2}{*}{ Information Flows } & 0.035 & -0.12 & 0.04 & 0.008 & -0.081 & -0.14 \\
\hline & $(0.56)$ & $(1.62)$ & $(0.6)$ & $(0.1)$ & $(1.2)$ & (1.12) \\
\hline Number of Countries & 59 & 59 & 59 & 59 & 59 & 59 \\
\hline R-squared & 0.08 & 0.06 & 0.01 & 0.06 & 0.04 & 0.03 \\
\hline \multirow[t]{2}{*}{ Cultural Proximity } & 0.032 & -0.009 & -0.021 & -0.066 & -0.037 & -0.061 \\
\hline & $(0.85)$ & $(0.19)$ & $(0.51)$ & (1.4) & $(0.91)$ & $(0.81)$ \\
\hline Number of Countries & 61 & 61 & 61 & 61 & 61 & 61 \\
\hline R-squared & 0.07 & 0.04 & 0.01 & 0.07 & 0.04 & 0.03 \\
\hline
\end{tabular}

Absolute value of $\mathrm{t}$ statistics in parentheses

* significant at $10 \%$; ** significant at $5 \%$; ** significant at $1 \%$ 
Table 6. Different types of globalization; sub-sample of high-income countries (controls included but not shown)

\begin{tabular}{|c|c|c|c|c|c|c|}
\hline & GE & CC & RQ & VA & RL & PS \\
\hline \multirow[t]{2}{*}{ Economic Flows } & 0.218 & 0.2 & 0.147 & 0.077 & 0.096 & 0.214 \\
\hline & $(2.96)^{* * *}$ & $(1.93)^{*}$ & $(1.25)$ & $(0.8)$ & $(1.14)$ & $(1.72)^{*}$ \\
\hline Number of Countries & 46 & 46 & 46 & 46 & 46 & 46 \\
\hline R-squared & 0.28 & 0.13 & 0.15 & 0.11 & 0.23 & 0.06 \\
\hline \multirow[t]{2}{*}{ Economic Restrictions } & -0.07 & -0.084 & 0.302 & 0.001 & -0.165 & -0.099 \\
\hline & $(0.64)$ & $(0.57)$ & $(1.93)^{*}$ & $(0.01)$ & (1.4) & $(0.58)$ \\
\hline Number of Countries & 44 & 44 & 44 & 44 & 44 & 44 \\
\hline R-squared & 0.21 & 0.09 & 0.21 & 0.07 & 0.26 & 0.03 \\
\hline \multirow[t]{2}{*}{ Personal Contacts } & 0.077 & 0.285 & -0.033 & 0.42 & -0.013 & 0.395 \\
\hline & $(0.35)$ & $(0.93)$ & $(0.1)$ & $(1.58)$ & $(0.06)$ & $(1.15)$ \\
\hline Number of Countries & 48 & 48 & 48 & 48 & 48 & 48 \\
\hline R-squared & 0.19 & 0.06 & 0.12 & 0.13 & 0.21 & 0.05 \\
\hline \multirow[t]{2}{*}{ Information Flows } & 0.212 & 0.466 & 0.098 & 0.201 & 0.122 & 0.185 \\
\hline & $(2.20)^{* *}$ & $(3.61)^{* * *}$ & $(0.7)$ & $(1.72)^{*}$ & (1.18) & $(1.24)$ \\
\hline Number of Countries & 47 & 47 & 47 & 47 & 47 & 47 \\
\hline R-squared & 0.22 & 0.14 & 0.18 & 0.13 & 0.24 & 0.04 \\
\hline \multirow[t]{2}{*}{ Cultural Proximity } & 0.066 & 0.066 & 0.032 & 0.101 & 0.028 & 0.096 \\
\hline & $(2.46)^{* *}$ & $(1.78)^{*}$ & $(0.8)$ & $(3.15)^{* * *}$ & $(0.97)$ & $(2.29)^{* *}$ \\
\hline Number of Countries & 48 & 48 & 48 & 48 & 48 & 48 \\
\hline R-squared & 0.23 & 0.08 & 0.13 & 0.18 & 0.22 & 0.08 \\
\hline
\end{tabular}

Absolute value of $\mathrm{t}$ statistics in parentheses

* significant at $10 \%$; ** significant at $5 \%$; ** significant at $1 \%$ 
In short, only liberalization of economic restrictions seem to do more good to institutions in low-income countries than in high-income countries. The other four aspects of globalization all capture some kind of human interaction such as trade, foreign investment, tourism, cultural integration and surfing the Internet. To the extent that increases in these activities affects institutions, it leads to improvements in high-income countries and to worse institutions in low-income countries. This is very much in line with our theoretical prior arguments and suggests that the results in previous studies using samples including rich and poor countries together should be interpreted with care.

\section{(b) Robustness tests}

To verify the robustness of our results, we include a number of additional control variables used in the empirical literature on institutional change: Political regime, represented by the Polity IV score, the share of adult population (age > 15) with completed secondary education and total net development assistance and aid.

The main difference between rich and poor countries remains when including these variables. As expected, Polity IV score is not significant given that it changes little over time. Education has a significant negative effect on political stability but is otherwise not significant. Most interestingly, aid is typically positive and significant, suggesting either that aid improves institutional quality or that more aid is given to countries where institutions are improving. ${ }^{9}$

\footnotetext{
${ }^{9}$ Previous findings have associated aid with a decline in institutional quality (Brautigam and Knack, 2004) or found it having only a small impact on institutional change (Knack 2004). However, according to Wright (2009), there are factors that might intervene in the aid-institutions relationship, causing aid to improve a country's accountability.
} 
In the main analysis, the strategy to identify differences between rich and poor countries is to divide the full sample. A different strategy is to include an interaction term between globalization and GDP. Doing so improves the power of the estimations and allows us to calculate the marginal effect of globalization on institutional quality at different levels of GDP per capita. Figure 2 (a) and (b) illustrate the marginal effect of globalization on control of corruption conditional on the value of logged GDP per capita, and confidence intervals at 95 percent. Once again the pattern found in our baseline analysis is confirmed: Economic globalization is followed by improved (here: less corrupted) institutions in rich but not in poor countries. Social globalization however seems to worsen institutions in poor but not in rich countries. 
Figure 2. The marginal effect of economic (a) and social (b) globalization on control of corruption at different levels of GPD per capita.

(a)

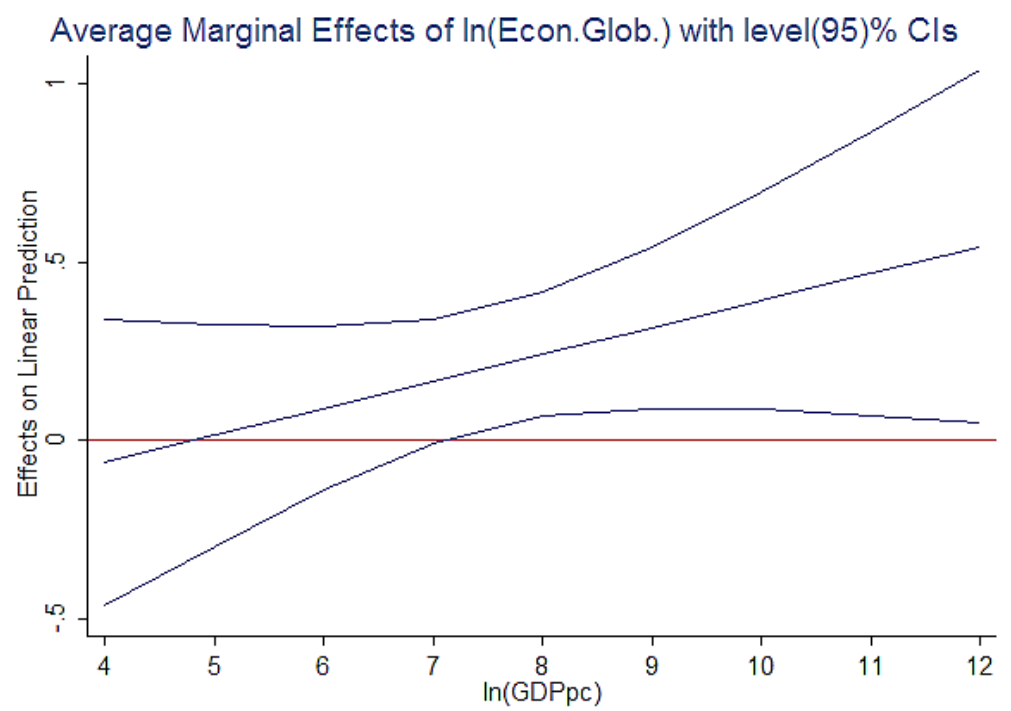

(b)

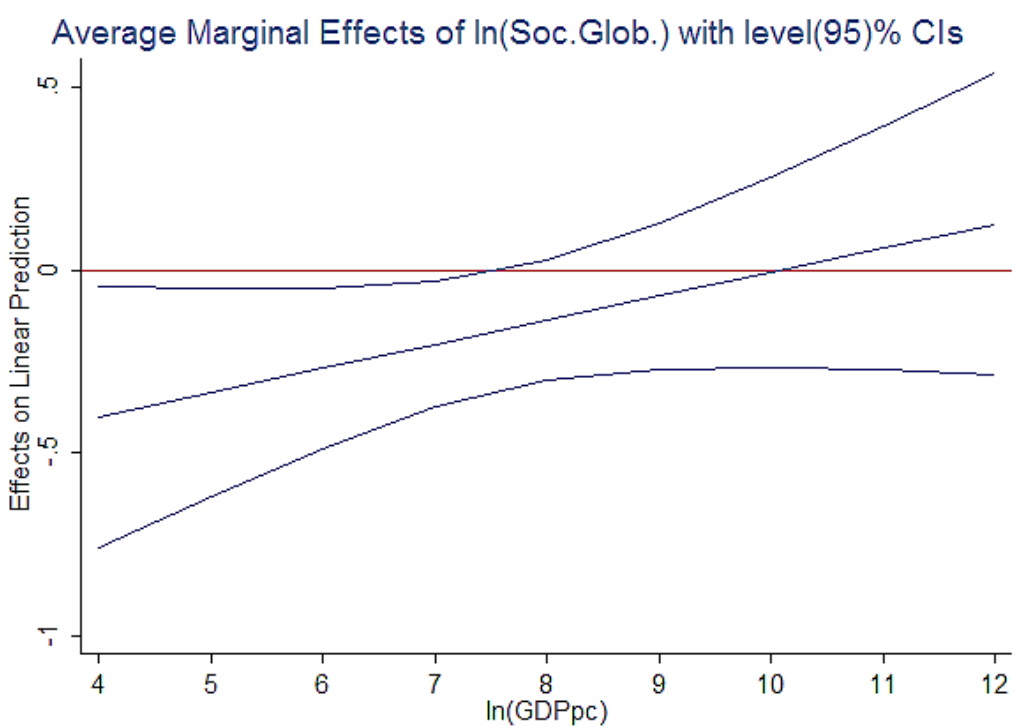




\section{CONCLUDING DISCUSSION}

(a) Explaining the heterogenous effect: Suggestions for further research

We have uncovered a heterogenous effect of globalization on institutions, where

In poor countries political power is often concentrated to an economic elite, for example the major producers and investors in the economy. Such organization calls for little institutional change to occur as influential agents have little incentives to e.g. improve property rights for the wider economy or reduce corruption by altering the existing framework. As long as the group who live off the fruits from globalization enjoy privileged access to a superior level of standard of living compared to the benefits that they would be able to have in case institutional quality improved, little change will take place. As discussed by Acemoglu (2008) the economic elite protect their property rights and ensure that they do not fear expropriation, but this type of organization also typically enable the elite to get a monopoly position for themselves and exclude others to take advantage of profit opportunities, in essence violating the property rights of future potential producers.

The time horizon and expectations of voters should therefor be crucial in determining the effects of increased globalization on institutions. Political participation is a set of activities (with voting as potentially the least demanding form of activity) aimed at influencing political decisions and/or imposing checks and balances on governments. The time horizon and expectations may directly and indirectly determine the degree to which people vote and demand accountability of local and national politicians. As shown by e.g. Campante and Chor (2011) there is a robust link between individual schooling and political participation. Shorter time horizonz and poverty in general also explains why schooling on average is lower in developing countries (c.f. Jayachandran and Lleras-Muney (2009) on how life expectancy lowers the value of human capital investments) 
The intensity of this link is further affected by societal characteristics, including the quality of political institutions and cultural attitudes. The rationale for testing the relationship between globalization and institutions separately in low- and high-income countries respectively is consequently also supported by recent micro economic evidence on the effects of human capital.

In 1749 Montesquieu suggested that market interactions may act as a civilizing force. Following his line of reasoning, the establishment of the Swedish furniture retailer IKEA in Russia in the year 2000 could affect norms and behavior in such manner that ensuing firms establishing in the country would not have to share similar experiences with bribes and corruption. If this held true globally, it would be welcome news for developing countries. Sadly however, this seems not to be the case.

Researchers have recently started to empirically examine the relationship between economic globalization and institutional quality. The existing literature does however not consider that the relationship between globalization and institutional change may differ across contexts of development. We add to a new and growing literature on openness and institutional quality, by arguing that the elites that influence institutions are likely to have different time horizons in low-income and high-income countries. As a result, increasing economic and social interactions following with globalization are likely to affect institutions differently depending on the level of development. Our empirical results show that this is indeed the case.

Using a panel dataset based on the World Governance Indicators and using the components of the KOF index as our globalization measures, we find striking differences in how institutions change under impact of economic flows and policies, and as well as of three different aspects of social globalization. Above all, the control of corruption seems to worsen when less developed countries trade more, but improve in globalizing high-income countries. Similarly, 
more social interaction across national borders seems to worsen institutional quality in poor contexts while the opposite holds when the level of economic development is higher. In contrast, more liberal trade policies seem to bring about positive institutional change in lowincome countries, suggesting that new set of constraints and new rules are more important than more economic transactions in this context.

Three major conclusions can be made from our findings. First, the globalization process is indeed multidimensional and different parts of the process (and their specific character) seem to affect institutions very differently. Second, different types of institutions seem to differ in how easily they respond to the new state of affairs that follows with more globalization. For example, although both the rule of law indicator and the control of corruption indicator capture how well citizens and the state respect institutions that govern economic and social interactions among them - it is mainly the control of corruption that is affected by the globalization process in this setting. Third, in line with the theoretical predictions, globalization affects institutions differently depending on the country level of development. This empirical support suggests that previous findings of positive effects of trade on institutional quality are likely driven by rich countries.

Examining the consequences of globalization on the World's poor is understandably a vivid research area. For example, Bergh and Nilsson (2010) demonstrated, also using the KOF globalization index, that both economic and social globalization are positively related to life expectancy, and that this relationship holds also when rich countries are excluded from the sample. In contrast, our results here rather suggest that globalization such as trade and tourism benefits institutional quality in rich countries but not in poor, and that previous studies have inappropriately pooled rich and poor countries. A suggestion for future research is therefore to examine closely (preferably using micro level data) the links between various forms of globalization and social norms and institutions in developing countries. 
Appendix

Table A1. The KOF Index of Globalization

A. Economic Globalization

i) Actual Flows

Trade (percent of GDP)

Foreign direct investment, flows (percent of GDP)

Foreign direct investment, stocks (percent of GDP)

Portfolio investment (percent of GDP)

Income payments to foreign nationals (percent of GDP)

ii) Restrictions

Hidden import barriers

Mean tariff rate

Taxes on international trade (percent of current revenue)

Capital account restrictions

B. Social Globalization

i) Data on Personal Contacts 
Outgoing telephone traffic

Transfers (percent of GDP)

International tourism

Foreign population (percent of total population)

International letters (per capita)

ii) Data on Information Flows

Internet hosts (per 1000 people)

Internet users (per 1000 people)

Cable television (per 1000 people)

Trade in newspapers (percent of GDP)

Radios (per 1000 people)

iii) Data on Cultural Proximity

Number of McDonald's restaurants (per capita)

Number of IKEAs (per capita)

Trade in books (percent of GDP)

C. Political Globalization

Embassies in country

Membership in international organizations

Participation in UN Security Council missions 
Table A2. The Worldwide Governance Indicators

(a) The process by which governments are selected, monitored, and replaced:

1. Voice and Accountability (VA) - capturing perceptions of the extent to which a country's citizens are able to participate in selecting their government, as well as freedom of expression, freedom of association, and a free media.

2. Political Stability (PS) - capturing perceptions of the likelihood that the government will be destabilized or overthrown by unconstitutional or violent means, including politicallymotivated violence and terrorism.

(b) The capacity of the government to effectively formulate and implement sound policies:

3. Government Effectiveness (GE) - capturing perceptions of the quality of public services, the quality of the civil service and the degree of its independence from political pressures, the quality of policy formulation and implementation, and the credibility of the government's commitment to such policies.

4. Regulatory Quality (RQ) - capturing perceptions of the ability of the government to formulate and implement sound policies and regulations that permit and promote private sector development. 
(c) The respect of citizens and the state for the institutions that govern economic and social interactions among them:

5. Rule of Law (RL) - capturing perceptions of the extent to which agents have confidence in and abide by the rules of society, and in particular the quality of contract enforcement, property rights, the police, and the courts, as well as the likelihood of crime and violence.

6. Control of Corruption (CC) - capturing perceptions of the extent to which public power is exercised for private gain, including both petty and grand forms of corruption, as well as "capture" of the state by elites and private interests. 
Table A2. The most representative sources for the Worldwide Governance Indicators

\begin{tabular}{|c|c|c|c|c|c|c|}
\hline \begin{tabular}{|l|} 
Worldwide \\
Governance \\
Indicators source
\end{tabular} & Government effectiveness & Control of corruption & Regulatory quality & Voice and accountability & Rule of law & $\begin{array}{l}\text { Political stability and } \\
\text { absence of violence }\end{array}$ \\
\hline Meaning & $\begin{array}{l}\text { Perceptions of the quality } \\
\text { of the civil service and the } \\
\text { degree of its independence } \\
\text { from political pressures, the } \\
\text { quality of policy } \\
\text { formulation and } \\
\text { implementation, and the } \\
\text { credibility of the } \\
\text { government's commitment } \\
\text { to such policies }\end{array}$ & $\begin{array}{l}\text { Perceptions of the extent } \\
\text { to which public power is } \\
\text { exercised for private } \\
\text { gain, including both } \\
\text { petty and grand forms of } \\
\text { corruption, as well as } \\
\text { "capture" of the state by } \\
\text { elites and private } \\
\text { interests }\end{array}$ & $\begin{array}{l}\text { Perceptions of the ability of } \\
\text { the government to formulate } \\
\text { and implement sound } \\
\text { policies and regulations that } \\
\text { permit and promote private } \\
\text { sector development }\end{array}$ & $\begin{array}{l}\text { Perceptions of the extent to } \\
\text { which a country's citizens } \\
\text { are able to participate in } \\
\text { selecting their government, } \\
\text { as well as freedom of } \\
\text { expression, freedom of } \\
\text { association, and a free media }\end{array}$ & $\begin{array}{l}\text { Perceptions of the extent to } \\
\text { which agents have } \\
\text { confidence in and abide by } \\
\text { the rules of society, and in } \\
\text { particular the quality of } \\
\text { contract enforcement, } \\
\text { property rights, the police, } \\
\text { and the courts, as well as } \\
\text { the likelihood of crime and } \\
\text { violence }\end{array}$ & $\begin{array}{l}\text { Perceptions of the } \\
\text { likelihood that the } \\
\text { government will be } \\
\text { destabilized or overthrown } \\
\text { by unconstitutional or } \\
\text { violent means, including } \\
\text { politically-motivated } \\
\text { violence and terrorism }\end{array}$ \\
\hline $\begin{array}{l}\text { Economist } \\
\text { Intelligence Unit }\end{array}$ & $\begin{array}{llr}- & \text { Quality } & \text { of } \\
& \text { bureaucracy } & / \\
\text { institutional } & \\
\text { effectiveness } & \\
- & \text { Excessive } & \\
\text { bureaucracy / red } \\
\text { tape }\end{array}$ & $\begin{array}{l}\text { - Corruption } \\
\text { among public } \\
\text { officials }\end{array}$ & $\begin{array}{ll}- & \text { Unfair competitive } \\
- & \text { practices } \\
- & \text { Price controls } \\
- & \text { Discriminatory } \\
& \text { tariffs } \\
- & \text { Excessive } \\
& \text { protections } \\
- & \text { Discriminatory } \\
& \text { taxes }\end{array}$ & $\begin{array}{lll}- & \text { Democracy Index } \\
- & \text { Vested interests } \\
- & \text { Accountability of } \\
& \text { public officials } \\
- & \text { Human rights } \\
- & \text { Freedom of } \\
& \text { association }\end{array}$ & $\begin{array}{lll}- & \text { Organized crime } \\
- & \text { Fairness of } \\
& \text { judicial process } \\
- & \text { Speediness of } \\
& \text { judicial process } \\
- & \text { Expropriation } \\
- & \text { Intellectual } \\
& \text { property rights } \\
\text { protection }\end{array}$ & $\begin{array}{ll}- & \text { Orderly transfers } \\
- & \text { Armed conflict } \\
- & \text { Violent } \\
& \text { demonstrations } \\
- & \text { Social unrest } \\
- & \text { International } \\
& \text { tensions } \\
& \text { terrorist threat }\end{array}$ \\
\hline Freedom House & & - $\quad$ Corruption & & \begin{tabular}{ll|}
- & Political rights \\
- & Civil liberties \\
- & Press Freedom \\
& Index \\
- & Civil society \\
- & Electoral process
\end{tabular} & $\begin{array}{ll}- & \text { Judicial } \\
& \text { framework and } \\
& \text { independence }\end{array}$ & \\
\hline
\end{tabular}




\begin{tabular}{|c|c|c|c|c|c|c|c|}
\hline \begin{tabular}{|l} 
World Economic \\
Forum Global \\
Competitiveness \\
Report
\end{tabular} & $\begin{array}{lll}- & \text { Infrastructure } & \\
- & \text { Quality } & \text { of } \\
& \text { primary } & \\
& \text { education } & \end{array}$ & $\begin{array}{ll}- & \text { Public trust in } \\
& \text { politicians } \\
- & \text { Diversion of } \\
& \text { public funds } \\
- & \text { Bribery: Trade } \\
- & \text { Bribery: } \\
& \text { Utilities } \\
- & \text { Bribery: Taxes } \\
- & \text { Bribery: } \\
& \text { Judiciary } \\
- & \text { State capture }\end{array}$ & \begin{tabular}{ll|}
- & Tax system \\
& distortionary \\
- & Trade barriers \\
- & Local competition \\
- & Ease of starting a \\
& new business \\
- & Anti-monopoly \\
& policy
\end{tabular} & 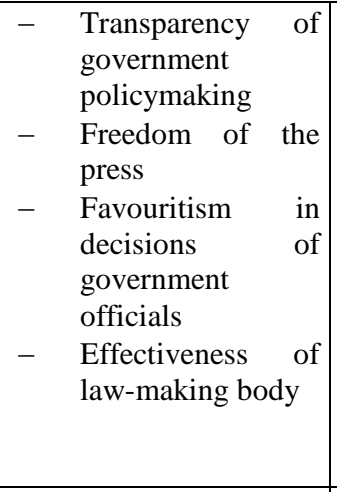 & 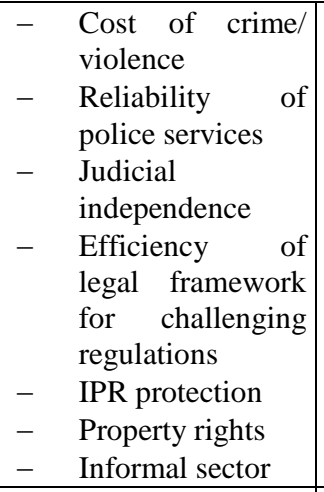 & - & Cost of terrorism \\
\hline $\begin{array}{l}\text { Gallup World } \\
\text { Poll }\end{array}$ & $\begin{array}{l}\text { Satisfaction with } \\
\text { public } \\
\text { transportation, } \\
\text { roads and } \\
\text { highways, and } \\
\text { with the } \\
\text { education system }\end{array}$ & \begin{tabular}{ll|}
- & Is corruption \\
in government \\
widespread?
\end{tabular} & & $\begin{array}{lll}- & \begin{array}{l}\text { Confidence } \\
\text { honesty }\end{array} & \text { in } \\
\text { elections } & \text { of }\end{array}$ & $\begin{array}{ll}- & \text { Confidence in the } \\
\text { police force } & \\
- & \text { Confidence in } \\
\text { judicial system } \\
- & \begin{array}{l}\text { Have you been } \\
\text { assaulted } \\
\text { mugged? }\end{array}\end{array}$ & & \\
\hline
\end{tabular}


Table A2. The most representative sources for the Worldwide Governance Indicators (cont.)

\begin{tabular}{|c|c|c|c|c|c|c|}
\hline \begin{tabular}{|l} 
Institutional \\
Profiles Database
\end{tabular} & 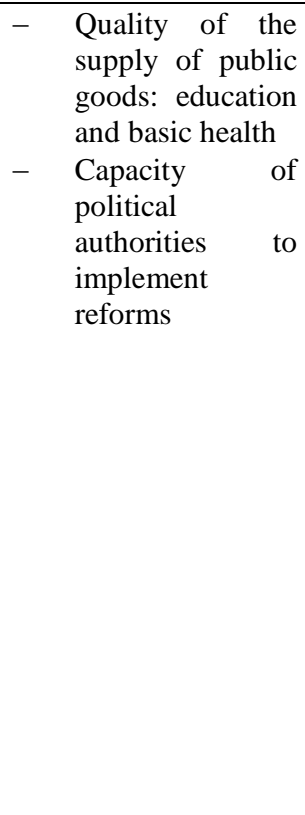 & $\begin{array}{l}- \text { Level of petty, } \\
\text { large-scale and } \\
\text { political } \\
\text { corruption }\end{array}$ & $\begin{array}{ll}- & \begin{array}{l}\text { Ease of Starting a } \\
\text { business }\end{array} \\
- & \text { Administered } \\
\text { prices and market } & \text { prices } \\
- & \text { Competition: } \\
\text { productive sector: } \\
\text { ease of market } \\
\text { entry for new } \\
\text { firms } \\
\text { Competition } \\
\text { between } \\
\text { businesses: } \\
\text { competition } \\
\text { regulation } \\
\text { arrangements }\end{array}$ & 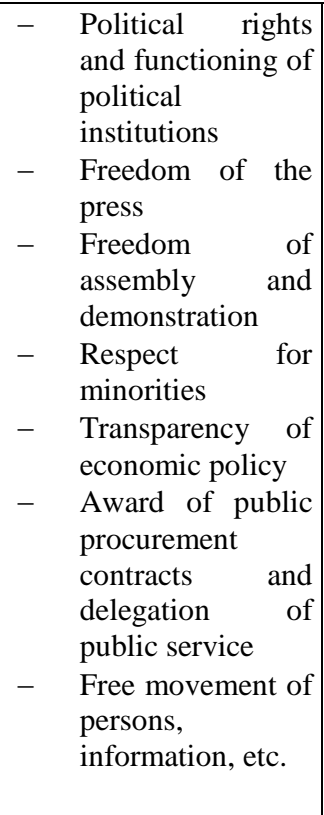 & 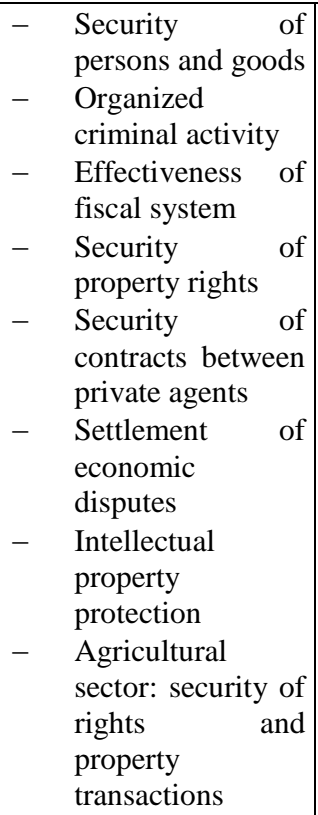 & 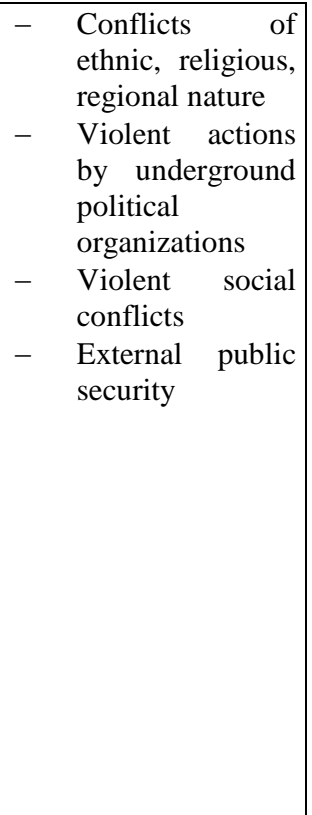 \\
\hline $\begin{array}{l}\text { International } \\
\text { Country Risk } \\
\text { Guide }\end{array}$ & $\begin{array}{ll}- & \text { Bureaucratic } \\
& \text { quality }\end{array}$ & - Corruption & - $\quad$ Investment profile & $\begin{array}{lll}- & \text { Military in } \\
& \text { politics } \\
- & \text { Democratic } & \\
& \text { accountability } & \end{array}$ & - $\quad$ Law and Order & $\begin{array}{ll}- & \text { Government } \\
& \text { stability } \\
- & \text { Internal conflict } \\
- & \text { External conflict } \\
- & \text { Ethnic tensions }\end{array}$ \\
\hline \begin{tabular}{|l|} 
Reporters \\
Without Borders
\end{tabular} & & & & $\begin{array}{lll}- & \text { Press } & \text { Freedom } \\
\text { Index } & \end{array}$ & & \\
\hline \begin{tabular}{|l} 
US State \\
Department
\end{tabular} & & & & & $\begin{array}{ll}- & \text { Trafficking } \\
\text { people }\end{array}$ & \\
\hline
\end{tabular}




\begin{tabular}{|c|c|c|c|c|c|c|c|c|c|c|}
\hline $\begin{array}{l}\text { Global Insight } \\
\text { Business } \\
\text { Conditions and } \\
\text { Risk Indicators }\end{array}$ & & $\begin{array}{l}\text { Bureaucracy } \\
\text { Policy } \\
\text { consistency and } \\
\text { forward planning }\end{array}$ & - & Corruption & $\begin{array}{ll}\text { - } & \text { Tax effectiveness } \\
\text { - } & \text { Legislation }\end{array}$ & & $\begin{array}{l}\text { Institutional } \\
\text { permanence }\end{array}$ & - & $\begin{array}{l}\text { Judicial } \\
\text { independence } \\
\text { Crime }\end{array}$ & $\begin{array}{ll}- & \text { Civil unrest } \\
- & \text { Terrorism }\end{array}$ \\
\hline Afrobarometer & - & $\begin{array}{l}\text { Government } \\
\text { handling of } \\
\text { public services } \\
\text { (health, } \\
\text { education) }\end{array}$ & $\begin{array}{l}- \\
- \\
-\end{array}$ & $\begin{array}{l}\text { How many } \\
\text { government } \\
\text { officials do you } \\
\text { think are } \\
\text { involved in } \\
\text { corruption? } \\
\begin{array}{l}\text { How many tax } \\
\text { officials do you } \\
\text { think are } \\
\text { involved in } \\
\text { corruption? }\end{array}\end{array}$ & & $\begin{array}{l}- \\
- \\
- \\
-\end{array}$ & $\begin{array}{l}\text { How much do you } \\
\text { trust the } \\
\text { parliament? } \\
\text { How satisfied are } \\
\text { you with the way } \\
\text { democracy works } \\
\text { in your country? } \\
\text { Free and fair } \\
\text { elections }\end{array}$ & - & 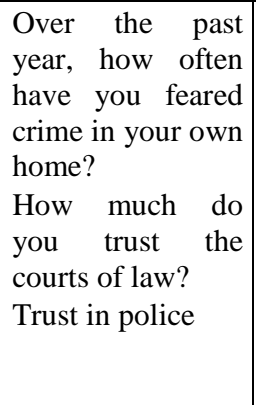 & \\
\hline
\end{tabular}


Table A3. Country list

\begin{tabular}{|c|c|c|c|c|c|}
\hline \multicolumn{3}{|c|}{ Low-income countries } & \multicolumn{3}{|c|}{ High-income countries } \\
\hline Afghanistan & Guinea & $\begin{array}{l}\text { Papua New } \\
\text { Guinea }\end{array}$ & Algeria & Iran & Saudi Arabia \\
\hline Albania & Guinea-Bissau & Paraguay & Andorra & Ireland & Serbia \\
\hline Angola & Guyana & Philippines & $\begin{array}{l}\text { Antigua and } \\
\text { Barbuda }\end{array}$ & Israel & Seychelles \\
\hline Armenia & Haiti & Rwanda & Argentina & Italy & Singapore \\
\hline Azerbaijan & Honduras & Samoa & Australia & Jamaica & Slovakia \\
\hline Bangladesh & India & $\begin{array}{l}\text { Sao Tome and } \\
\text { Principe }\end{array}$ & Austria & Japan & Slovenia \\
\hline Belize & Indonesia & Senegal & Bahamas & Kazakhstan & South Africa \\
\hline Benin & Iraq & Sierra Leone & Bahrain & Korea South & Spain \\
\hline Bhutan & Jordan & Solomon Islands & Barbados & Kuwait & $\begin{array}{l}\text { St Kitts and } \\
\text { Nevis }\end{array}$ \\
\hline Bolivia & Kenya & Somalia & Belarus & Latvia & St Lucia \\
\hline $\begin{array}{l}\text { Bosnia and } \\
\text { Herzegovina }\end{array}$ & Kiribati & Sri Lanka & Belgium & Lebanon & $\begin{array}{l}\text { St Vincent and } \\
\text { the Grenadines }\end{array}$ \\
\hline Burkina Faso & Korea North & Sudan & Botswana & Libya & Suriname \\
\hline Burundi & Kyrgyzstan & Swaziland & Brazil & Liechtenstein & Sweden \\
\hline Cambodia & Laos & Syria & Brunei & Lithuania & Switzerland \\
\hline Cameroon & Lesotho & Taiwan & Bulgaria & Luxembourg & Thailand \\
\hline Cape Verde & Liberia & Tajikistan & Canada & Macedonia & $\begin{array}{l}\text { Trinidad and } \\
\text { Tobago }\end{array}$ \\
\hline $\begin{array}{l}\text { Central African } \\
\text { Republic }\end{array}$ & Madagascar & Tanzania & Chile & Malaysia & Tunisia \\
\hline Chad & Malawi & Timor-Leste & Colombia & Malta & Turkey \\
\hline China & Maldives & Togo & Costa Rica & Mauritius & Ukraine \\
\hline Comoros & Mali & Tonga & Croatia & Mexico & $\begin{array}{l}\text { United Arab } \\
\text { Emirates }\end{array}$ \\
\hline Congo & Marshall Islands & Turkmenistan & Cyprus & Monaco & United Kingdom \\
\hline $\begin{array}{l}\text { Congo } \\
\text { Democratic } \\
\text { Republic }\end{array}$ & Mauritania & Tuvalu & Czech Republic & Montenegro & United States \\
\hline Cote d'Ivoire & Micronesia & Uganda & Denmark & Netherlands & Uruguay \\
\hline Cuba & Moldova & Uzbekistan & Dominica & New Zealand & Venezuela \\
\hline Djibouti & Mongolia & Vanuatu & $\begin{array}{l}\text { Dominican } \\
\text { Republic }\end{array}$ & Norway & \\
\hline Egypt & Morocco & Vietnam & Ecuador & Oman & \\
\hline El Salvador & Mozambique & Yemen & Estonia & Palau & \\
\hline $\begin{array}{l}\text { Equatorial } \\
\text { Guinea }\end{array}$ & Myanmar & Zambia & Finland & Panama & \\
\hline Eritrea & Namibia & Zimbabwe & France & Peru & \\
\hline Ethiopia & Nauru & & Gabon & Poland & \\
\hline Fiji & Nepal & & Germany & Portugal & \\
\hline Gambia & Nicaragua & & Greece & Qatar & \\
\hline Georgia & Niger & & Grenada & Romania & \\
\hline Ghana & Nigeria & & Hungary & Russia & \\
\hline Guatemala & Pakistan & & Iceland & San Marino & \\
\hline
\end{tabular}




\section{REFERENCES}

Abdiweli, A.M. (2003). Institutional Differences as Sources of Growth Differences. Atlantic

Economic Journal, 31, 348-362.

Acemoglu, D (2008). Oligarchic versus democratic societies. Journal of the European

Economic Association, 6, 1-44

Acemoglu, D., S. Johnson, \& J. A. Robinson. (2001). The Colonial Origins of Comparative

Development: An Empirical Investigation, American Economic Review, 91, 1369-1401.

Acemoglu, D., \& Robinson J. A. (2006). De Facto Political Power and Institutional

Persistence. The American Economic Review, 96, 325-330.

Acemoglu, D. \& T. Verdier. (2000) The Choice between Market Failures and Corruption, The American Economic Review, 90, 194-211.

Ades, A., \& Di Tella, R. (1999). Rents, Competition, and Corruption. American Economic Review, 89, 982-993.

Al-Marhubi, F.A. (2005). Openness and Governance: Evidence Across Countries. Oxford Development Studies, 33, 453-471.

Altindag, D. T. \& J. Xu. (2009) The Impact of Institutions and Development on Happiness, Departmental Working Papers 2009-17, Department of Economics, Louisiana State University.

Anthonsen, M., Löfgren, Å., Nilsson, K., \& Westerlund, J. (2012). Effects of rent dependency on quality of government. Economics of Governance, 13, 145-168. 
Arribas, I., Perez, F., \& Tortosa-Ausina, E. (2009). Measuring Globalization of International Trade: Theory and Evidence. World Development, 37, 127-127.

Barro, R. \& J. Lee. (2010). A New Data Set of Educational Attainment in the World, 19502010. NBER Working Paper No. 15902

Bergh, A. \& R. Höijer (eds.). (2008). Institutional Competition. Cheltenham: Edward Elgar Publishing.

Bergh, A. \& T. Nilsson. (2010). Good for living? On the relation between globalization and life expectancy. World Development 38, 1191-1204.

Bhattacharyya, S. (2012). Trade liberalization and institutional development. . Journal of Policy Modeling, 34, 253-269.

Blonigen, B.A., \& Wang, M.G. (2005). Inappropriate pooling of wealthy and poor countries in empirical FDI studies. NBER Working Paper 10378. National Bureau of Economic Research, Cambridge, MA.

Bonaglia, F., de Macedo, J.B., \& Bussolo, M. (2001). How Globalisation Improves Governance: OECD Working Papers 2001:181.

Brautigam, D., \& S. Knack. (2004). Foreign Aid, Institutions, and Governance in SubSaharan Africa. Economic Development and Cultural Change, 52, 255-285.

Campante, F., \& and Chor, D. (2011) Schooling, Political Participation, and the Economy, Review of Economics \& Statistics, 93, 1-71.

Chauvet, L., \& Collier, P. (2008). What are the Preconditions for Turnarounds in Failing States? Conflict Management and Peace Science, 25, 332-348. 
Daokui Li, D., Feng, J., \& Jiang, H. (2005). Institutional Entrepreneurs. American Economic Review, 96(2), 358-362.

Doucouliagos, C., \& Ulubasoglu, M.A. (2006). Economic freedom and economic growth: Does specification make a difference? European Journal of Political Economy, 22, 60-81.

Dreher, A. (2006). Does Globalization Affect Growth? Empirical Evidence from a new Index. Applied Economics, 38, 1091-1110.

Dreher, A., Gaston, N., \& Martens, P. (2008). Measuring Globalisation: Gauging Its Consequences: Springer.

Durlauf, S., Johnson, P., \& Temple, J. (2005). Growth Econometrics. In P. Aghion, and S.N. Durlauf (Eds.), Handbook of Economic Growth: North-Holland.

Hirschman, A. O. (1982). Rival interpretations of market society: Civilizing, destructive, or feeble? Journal of Economic Literature, 20, 1463-1484.

Fisman, R. \& R. Gatti. (2002). Decentralization and Corruption: Evidence Across Countries. Journal of Public Economics, 83, 325-345.

Fjeldstad, O. \& B. Tungodden. (2003) Fiscal Corruption: A Vice or a Virtue? World Development, 31, 1459-1467. doi: 10.1016/S0305-750X(03)00089-5

Haggard, S., \& Tiede, L. (2011). The Rule of Law and Economic Growth: Where are We? World Development, 39, 673-685.

Jayachandran, S. \& Lleras-Muney, A. (2009). Life Expectancy and Human Capital Investments: Evidence from Maternal Mortality Declines. The Quarterly Journal of Economics, 124, 349-397. 
Kaufmann, D., Kraay, A., \& Mastruzzi, M. (2005). Governance Matters IV: New Data, New Challenges The World Bank.

Kaufmann, D., A.Kraay \& Massimo Mastruzzi. (2010). The worldwide governance indicators: methodology and analytical issues, Policy Research Working Paper Series 5430, The World Bank.

Knack, S. (2004). Does Foreign Aid Promote Democracy? International Studies Quarterly, 48, 251-266.

Knack, S., \& Keefer, P. (1995). Institutions and Economic Performance: Cross-Country Test Using Alternative Institutional Measures. Economics and Politics, 7, 207-227.

Kramer, A. E. (2009). Ikea Tries to Build Public Case Against Russian Corruption. The New York Times, September 11, 2009.

Levchenko, A.A. (2011). International Trade and Institutional Change. NBER Working Paper No. 17675.

Marshall, Monty G. \& Keith Jaggers. (2012). Polity IV project: Political regime characteristics and transitions, 1800-2010. The Polity IV dataset. Retrieved from http://www.systemicpeace.org/polity/polity4.htm

Nicolini, M., \& Paccagnini, A. (2011). Does Trade Foster Institutions? Review of Economics and Institutions, 2.

North, D. C., Five Propositions about Institutional Change, in Explaining Social Institutions, Jack Knight and Itai Sened, eds., University of Michigan Press, 1995, pp. 15-26.

OECD. (2009). Focus on Citizens: Public Engagement for Better Policy and Services, OECD Studies on Public Engagement, OECD Publishing. doi: 10.1787/9789264048874-en 
Richter, B. K., \& Timmons, J.F. (2012). Why Not Adopt Better Institutions? Oxford Development Studies, 40, 272-281.

Rodrik, D. (2000). Institutions for High-Quality Growth: What They are and How to Acquire Them, NBER Working Paper No. 7540.

Rodrik, D., Subramanian, A., \& Trebbi, F. (2004). Institutions Rule: The Primacy of Institutions Over Geography and Integration in Economic Development. Journal of Economic Growth, 9, 131-165.

Romer, P.M. (1990). Endogenous Technological Change. Journal of Political Economy, 98, 71-102.

Teorell, J., M. Samanni, Sören Holmberg, \& Bo Rothstein. (2011). The Quality of Government Dataset, version 06.04.11. Gothenburg: The Quality of Government Institute. Retrieved from http://www.qog.pol.gu.se

Treisman, D. (2000). The causes of corruption: a cross-national study. Journal of Public Economics 76, 399-457.

Wacziarg, R., \& Welch, K.H. (2003). Trade Liberalization and Growth: New Evidence. NBER Working Paper 10152. Cambridge, Mass.: National Bureau of Economic Research.

Wei, S.J. (2000). Natural Openness and Good Government. NBER Working paper 7765.

World Bank. (2010). World Development Indicators. Washington, D.C.: World Bank.

Wright, J. (2009). How Foreign Aid Can Foster Democratization in Authoritarian Regimes. American Journal of Political Science, 53(3), 552-571. 